Technology database

\section{Best buys in UK research}

EVERY researcher in Britain is to be mailed on behalf of an on-line computer database, designed to sell British talents to industry worldwide. Called British Expertise in Science and Technology (BEST), the commercially run database has been endorsed by the British government and the Science and Engineering Research Council (SERC).

Researchers in universities, polytechnics and the research councils are being asked to take part in the programme, in part intended to provide the supposed missing link between researchers and industrialists. Thirteen thousand records on researchers and their work now constitute the core of the database. A typical record will show a researcher's qualifications, publications, past and present research work, specialities, peripheral interests, industrial experience, current and previous positions. With the appropriate telecommunications link, the database can be tapped from any part of the world.

The database is part of the response by British universities to the publication in June 1983 of the report by the government's Advisory. Council for Applied Research and Development (ACARD), which urged closer links on research between higher education and industry. In 1984, the universities set up a committee representing government departments and agencies as well universities and polytechnics. The committee selected the best proposal by Longman Cartermill, part of the Longman publishing house, from among other bids submitted.

Since the launch of the database in the spring, the operators claim to have attracted more than 100 industrial subscribers. Data entries to the system are free. Revenue will derive from subscribers, who are charged $£ 200$ for a single search or fees ranging up to $£ 10,000$ a year for full corporate use.

The terms of an agreement between SERC and the operators have yet to be concluded, but to start with, SERC will provide information on its research grants in return for access to the database for its own purposes.

Bill Johnstone - Meanwhile, the British Library is to launch its separate on-line computer database this week. That will focus more on research projects than researchers. The database contains 65,000 records of research being conducted in Britain. The system, called Current Research in Britain (CRIB), has evolved from an annual printed publication produced by the library. It has a $£ 50$-an-hour connection charge and is operated for the British Library by Pergamon InfoLine.

Information technology Filling the post-Alvey gap

A $\mathfrak{E}_{1,000}$ million five-year plan to strengthen Britain's research in and application of information technology was proposed last week by the IT86 committee, set up this spring under Sir Austin Bide, the now-retired chairman of the Glaxo pharmaceutical group. The request for funds on this unprecedented scale is meant to continue the five-year Alvey programme of research and development in information technology, whose $£ 350$ million is now almost fully committed.

More than 300 projects have been approved under the Alvey programme, but the Bide committee considers it too soon to evaluate their success except to say that they have been successful in drawing industry and universities together more closely "than was previously the case". The committee also says the programme has stimulated collaboration between companies normally in competition.

Of the total $£ 1,000$ million, the committee proposes that roughly $£ 425$ million should come from the British government and the remainder from industry. The government contributed $£ 200$ million to the total cost of Alvey projects.

The Bide committee estimates that the research element in the continuation programme will cost $£ 550$ million, of which the government is expected to contribute $£ 300$ million. As under Alvey, academic research would be fully supported by government, but research by industrial companies receives only halfsupport.

The committee also endorses some of the conclusions of a report by the British government's Advisory Council for Applied Research and Development (ACARD) which, earlier this year, was critical of the British software industry.
That document forecast a continued increase in the British trade deficit in information technology.

Much of the Bide committee's emphasis is on the need for converting research into marketable products. The committee says that applications schemes must involve collaboration between researchers and industry and that academic contributions to joint ventures should "go well beyond" traditional information-technology departments. The report also includes a long shopping-list of projects to be supported. Among applications projects, it singles out security systems, clinical data processing, interactive distance learning aids, distance learning for management, manufacturing control, electronic funds transfer at point of sale and software for railway signalling.

On research, the Bide committee recommends a number of areas to which effort should be directed, including systems design and management and new programming tools. Not all the support now requested need be new money; part of it may come from the funds already earmarked for the second phase of the European Strategic Programme for Research and Development in Information Technology (ESPRIT).

No doubt in recognition of the difficulty of extracting large amounts of money from the budgets of individual government departments, the committee says that the funds should come not only from the original sponsors of the Alvey programme (the Departments of Trade and Industry and of Defence and the Science and Engineering Research Council) but from other departments with an interest in the applications suggested, either as sponsors or as users.

\section{IMAGE \\ UNAVAILABLE FOR COPYRIGHT REASONS}

The Straits of Gibraltar, with Spain to the left and North Africa to the right. On page 313 of this issue we publish a 20-page supplement on science in the Iberian peninsula. Photo: Oblique view from Skylab, courtesy NASA. 